$\mathrm{C}_{6}: \mathrm{C}_{3}$ units, of which it is composed, are condensed together in a random fashion. The development of methods for determining the sequence of these units in the polymer is, therefore, awaited with great interest. The shikimic acid pathway is also utilized by plants for the formation of flavonoids. Prof. H. Grisebach (University of Freiburg) described recent theories regarding the synthesis of these pigments. These involve the condensation of cinnamic acids with malonyl-CoA, but so far the formation of the necessary activated cinnamic acids has not been demonstrated using plant enzymes.

The early stages of hæm and chlorophyll biosynthesis follow a common pathway and this has been deduced mainly by investigations with preparations from animal tissues and photosynthetic bacteria. Dr. J. Lascelles (University of Oxford) outlined this chain of reactions and gave an account of the interesting investigations which are in progress, using Chlorella mutants and photosynthetic bacteria, on the final stages in chlorophyll synthesis.

The final paper in the symposium, by Prof. S. L. Ranson (University of Newcastle), was concerned with the form. ation of aliphatic carboxylic acids by plants. Some of these, such as malate, eitrate and oxalate, commonly accumulate to a relatively high concentration in the cell. Others, such as fumarate and aconitate, accumulate infrequently. Why some cells accumulate one acid and others a different acid is a problem which remains to be settled.

The Group is indebted to the University of Leeds for the facilities which were placed at its disposal at Bodington Hall. Profs. F. C. Happold, I. Manton and R. D. Preston, all from the University, kindly acted as chairmen during three of the symposium sessions.

J. B. Pridham

${ }^{1}$ Elbein, E. D., Barber, G. A., and Hassid, W. Z., J. Amer. Chem. Snc., 86, $309(1964)$.

\title{
UNUSUAL FORMS AND ASPECTS OF CANCER IN MAN
}

$\mathrm{E}^{\mathrm{I}}$ THER too much or too little tends to be made of the rarities in medicine: purely chance phenomena are described in extenso, whereas sight is lost of significant observations in the flood of scientific literature. The conference held by the New York Academy of Sciences on "Unusual Forms and Aspects of Cancer in Man", in October 1963 (ref. 1), was an attempt to assess the importance of certain cancer rarities by grouping them together and discussing them in open forum. Many of the data and views presented at the conference had previously been put forward elsewhere. However, earlier communications were scattered through a variety of journals and several were not widely known. The publication of the proceedings of the conference therefore constitutes a valuable sddition to the medical literature.

The comparative value of different types of cancer treatment can be assessed relatively simply, but it is less easy to assess the value of treatment per se during an era in which almost every case receives some form of therapy. From his survey of 250 female cases of untreated breast cancer included in the 1805-1933 records of the Middlesex Hospital Charity, Bloom ${ }^{2}$ comes to essentially the same conclusions as Doland ${ }^{3}$, Greenwood ${ }^{4}$ and Nathanson and Welch $^{5}$. He records a mean survival period of $3 \frac{1}{4}$ years from the onset of symptoms, with almost 20 per cent of patients surviving for 5 years and 3 per cent for 10 years. Bloom is satisfied that all generally accepted methods of treatment both prolong life and reduce suffering from the effects of the disease. On the other hand, it appears that no measurable improvement in the results of treatment of breast cancer has occurred during the past few decades ${ }^{6}$. The possible value of radiography in the detection of early breast cancer has becn under investigation for more than thirty years, but, mainly because of failures in techniques, it has not found general favour. It is now clear that, in the hands of the expert, mammography sometimes results in the detection of breast cancer before th positive diagnosis could be made clinically by inspection and palpation ${ }^{6,7}$. Nevertheless, in the opinion of Egan ${ }^{6}$ it is too early to opine whether biannual mammography should be used to screen the female population for early breast cancer.

In an age of nuclear weapons, the carcinogenic effect of ionizing radiation is a political issue. It has therefore achieved more prominence than is justified by the facts. Investigations on the survivors of Hiroshima and Nagasaki $^{8}$ revealed the expected excesses of myeloid leukæmia ${ }^{9}$ and thyroid cancer ${ }^{10}$. In addition, an excess of anæmia due to myelofibrosis has been observed. Many of the thyroid cancers were microscopic and did not contribute to the death of the victim. Moreover, the incidence of small foci of thyroid cancer has not been adequately investigated in comparable unirradiated populations. This raises another problem. One is apt to assume that there is little scope these days for changes in standards of diagnosis. In fact, attempts at earlier diagnosis ${ }^{6, ?}$, increasing autopsy rates, the classification of microscopic lesions as cancer ${ }^{8,11,12}$, and a gathering interest in aged patients ${ }^{13}$ are steadily altering the background against which other more closely investigated events are studied.

It is generally held that the majority of lung cancers arise in the large bronchi within a few inches of the bifurcation of the trachea. It is within the same areas that the particulate matter present in inhaled tobacco smoke and polluted air tends to be deposited ${ }^{14}$. Rigler presents a survey of patients in whom routine chest roentgenograms were taken at intervals prior to the diagnosis of lung cancer. The first radiological signs were usually present almost a year before the onset of significant symptoms. In some cases the interval between the first sign and the making of a definitive diagnosis was as long as 5-10 years. The finding that the majority of tumours arose in the lung periphery and were not symptomatic until they had spread centrally is surprising, since it suggests that the deposition of particulate matter is not closely related to cancer induction. One wonders how often centrally arising tumours would have been detected radiologically in their early stages, and to what extent Rigler's conclusions are influenced by the fact that they are based on selected material.

Successful treatment of cancer discovered during pregnancy may involve the loss of the foetus. Most would regard this loss as an unfortunate necessity, but whether the discovery of cancer per se provides grounds for the deliberate termination of pregnancy is another matter. Rarely, cancer cells cross the placental barrier and grow metastatically in the foetus ${ }^{15,16}$. The demonstration of so-called vertical transmission of murine leukæmia viruses ${ }^{17,18}$ prompts the search for examples of similar transmission of tumour viruses in man. However, as yet no human tumour viruses have been positively identified. A few forms of cancer have an undoubted familial tendency. It is exceptionally rare for one of these types of cancer to be diagnosed for the first time during preg. nancy. Cancer during childhood is rare, and the occurrence of two cases in one family suggests a transmitted genetic or viral factor. Dargeon ${ }^{15}$ records six examples of malignant disease arising in two children of the same family: in no case was it possible to say whether these arose as the result of coincidence, transmission of a genetic 
aberration, or transmission of a tumour virus, and in no case was malignant disease recorded in tho mother during or before either of the pregnancies. The remaining consideration is whether the continuance of the pregnant state adversoly affects the progress of the cancer. This is a complicated question without any clear answer. Most would agree that it is necessary to judge each case separately on its merits.

If cancerous foci of microscopic dimensions are taken into consideration, the incidence of multiple primary malignant neoplasms is relatively high. Moertel ${ }^{18}$ writes, "The traditional concept of carcinoma as a single neoplasm intruding in an otherwise normal tissue is not always tenable. In a significant number of cases the initial nooplasm is only the first and most obvious manifestation of a carcinogenic process that may involve a large portion, or all, of a given tissue". Mersheimar, Ringel and Eisenberg's ${ }^{20}$ results suggest that second cancers arise in the same tissue or system more frequently than would be expected by chance where the first cancer was in the breast, skin, colon, rectum or genito-urinary tract. According to Moertel ${ }^{19}$, these findings should be taken into account in deciding the best treatment for cancers of these sites.

A series of contributions on the occurrence and treatment of certain uncommon or rare neoplasms are valuable for reference purposes. Of more general interest are papers on the relation between immune mechanisms and cancer and on the spontaneous regression of cancer. According to Grace ${ }^{21}$, the immunological impairment not infrequently observed in cancer patients ${ }^{22,23}$ is often related to disease directly affecting the lymphatic system. On the other hand, there are several examples of patients reacting immunologically to components or products of their own tumours; and the failure of advanced cancer patients to accept autografts of their own tumours is a puzzling phenomenon which needs further investigation. Everson's ${ }^{24}$ survey of examples of the spontaneous regression of cancer is superb and it would be fitting to conclude this article with his assessment of the significance of this phenomenon: "(1) The existence of spontaneous regression of cancer, in at least some cases, supports the concept of biologic control of cancer and reinforces the hope that a more satisfactory method of treating cancer than surgery, and/or radiation, may be found in future years.

"(2) The occurrence of spontaneous regression of cancer demonstrates the need for caution in the assessment of the value of chemotherapeutic and unorthodox therepeutic measures in isolated 'cures' of cancer.

"(3) The possibility of spontaneous regression of cancer must be considered in the evaluation of the prognosis of certain cancers. The remote possibility of spontaneous regression of cancer may be of some psychotherapeutic value in the patient with cancer which is not amenable to surgical and/or radiation treatment." F. J. C. RoE

1 Moss, N. Henry, Warren, S., Pack, George T., and 56 other authors. Ann. N.Y.Acad. Sci. 114, Article 2. Unusual Forms and Aspects of Ann. N.Y. Aad. Sci., 114, Article 2: Y Nusual Forms and Aspects of Sciences, 1964.) 7.50 dollars.

${ }^{2}$ Bloom, H. J. G., Ann. N.Y. Acad. Sci., 114, 747 (1963).

s Doland, E. M., Surg., Gynecol. Obstet., 44, 264 (1927).

Greenwood, M., Rep. Publ. Hlth Med. Subj., No. 33 (London: H.M.S.O., 1926).

s Nathanson, I. T., and Welch, C. E., Amer. J. Cancer, 28, 40 (1936).

- Egan, R. L., Ann. N.Y. Acad. Sci., 114, 794 (1963).

"Gershon-Cohen, J., and Borden, A. G. B., Ann. N.Y. Acad. Sci., 114, 782 (1963).

${ }^{8}$ Angevine, D. M., and Jablon, S., Ann. N.Y. Acad. Sci., 114, 823 (1963).

Brill, A. B., Tomonago, M., and Heyssel, R. M., Ann. Int. Med., 56, 590 (1962).

${ }^{10}$ Pifer, J. W., and Hempelmann, L. H., Ann. N.Y. Acad. Sci., 114, 838 (1963)

${ }^{11}$ Franks, L. M., Ann. Roy. Coll. Surgeons England, 14, 92 (1954).

12 Auerbach, O., and Stout, A. P., Ann. N.Y. Acad. Sci., 114, 803 (1963).

${ }^{13}$ Cutler, S. J., and Eisenberg, H., Ann. N.Y. Acad. Sci., 114, 771 (1963).

${ }^{14}$ Ermala, P., and Holsti, L. R., Cancer, 8, 673 (1955).

${ }_{15}$ Dargeon, H. W., Ann. N.Y. Acad. Sci., 114, 767 (1963).

${ }^{16}$ Willis, R. A., The Pathology of Tumours of Children (London: Oliver and Boyd, 1962).

${ }^{17}$ Gross, L., Proc. Soc. Exp. Biol., N.Y., 78, 342 (1951).

${ }^{18}$ Salaman, M. H., and Harvey, J. J., Nature, 191, 509 (1961).

${ }^{19}$ Moertel, C. G., Ann. N.Y. Acad. Sci., 114, 886 (1963).

${ }^{20}$ Mersheimar, W. L., Ringel, A., and Eisenberg, A., Ann. N.Y. Acad. Sci., 114, 896 (1963).

${ }^{22}$ Grace, J. T., Ann. N.Y. Acad. Sci., 114, 736 (1963).

${ }^{22}$ Grace, J. T., and Kondo, T., Ann. Surg., 148, 633 (1958).

${ }^{23}$ Southam, C. M., and Brunschwig, A., Cancer, 14, 971 (1961).

${ }^{24}$ Everson, T. C., Ann. N.Y. Acad. Sci., 114, 721 (1963).

\section{BRITISH TECHNICAL CO-OPERATION OVERSEAS}

$I^{\mathrm{N}}$ replying to a series of questions in the House of Commons on June 25, the Secretary for Technical Co-operation, Mr. R. Carr, said that he was charged to give the sort of help to the developing countries which they themselves said they most needed. British Embassies and High Commissions kept under review the progress and results of his Department's work, and specialist advisers and other staff from his Department made frequent tours overseas. The $£ 175$ million spent on overseas aid this year was a record figure and illustrated the rapid rate of expenditure over recent years. Consultation with the Agency for International Development in the United States was close and continuous. The 2,900 recruited under the auspices of the British Government in 1963 for service in the developing countries included a very small number not of British nationality; the 1962 figure was 2,300. Questioned as to alleged difficulties experionced by professional people in finding suitable employment on return to Britain from service overseas, $\mathbf{M r}$. Carr said that the Overseas Services Resettlement Bureau has been set up specially to assist members of the Overseas Civil Service retiring prematurely, and was doing so with outstanding success. His Department did all it could to encourage employers to release staff on terms which provide for their re-absorption and also to encourage general recognition that overseas service is of positive value in a professional career. $\mathrm{He}$ would welcome assistance in making the arrangements better known.

On Latin America, he said that more than $£ 500,000$ had been allocated from his Department's funds in this financial year compared with $£ 90,000$ in 1963, and this represented about 2 per cent of Britain's total bilateral technical assistance expenditure and about 20 per cent of that allocated to foreign countries. Much of the $£ 400,000$ allocated by the British Council to Latin America was also for technical assistance, and he hoped there would be 70 experts in Latin America by the end of the year. Britain could probably help most in agriculture and natural resources work and in technical education.

During the past 12 months, Mr. Carr said he had had requests for training in the United Kingdom of 20 Indians for maintaining and operating new plant to be installec. at the Durgapur Steel Works; for 4 engineering experts to assist the chief construction engineer; and for continuing the services of the British general manager until September 1965. More than 400 Indian steel workers had been trained in Britain, and Britain had also supplied substantial managerial and technical staff to the Durgapur Steel Works. Mr. Carr estimated that Britain's expenditure on technical assistance in Malaysia, excluding the Overseas Aid Service, would be about 50 per cent higher in 1964-65 than in 1962-63. 